\title{
メパニピリム：薬棛で誘起されたゴルジ装置分散の新規な阻害剂 一ゴルジ装置ダイナミクスの機構を解明するツール—
}

\author{
${ }^{1}$ 理研・動物・細胞システム，2茨城大・資源生物（現 *三共・探索研，**法政大・工・物資化学） \\ 中村真知子 $1,2 *$, 河野芳樹 ${ }^{2}$, 高月 昭 $1 * *$
}

Biosci. Biotechnol. Biochem., 67(1), 139-150 (2003)

はじめに

1898 年にC. Golgiによって発見されたゴルジ装置は, タンパク質や脂質の細胞内輸送や複合糖質の糖鎖合成に中 心的な役割を果たしていることから，その機能について活 発な研究が展開されてきた。ゴルジ装置は非常にダイナミ ックな構造体である。すなわち， 5 分間にゴルジ装置を構 成する量に相当するタンパク質が運ばれてくる例ああるよ うに，ゴルジ装置には多種多様な多量の輸送物資が出入り しているにもかかわらず，その構造的・機能的恒常性を維 持している。また，核構造体と同様に，ゴルジ構造体は動 物細胞では細胞分裂の初期には消失し後期に速やかに再構 築される. しかし，ゴルジ装置の機能に比べてそのダイナ ミクスについては多くが明らかにされていない.

糖タンパク質糖鎖の合成と機能の研究に扔けるッ二カマ イシンや細胞内輸送の研究におけるブレフェルジン A のよ うに，特異な阻害剤は有用なッールとなることを経験してき た、ゴルジ装置ダイナミクスの研究に扔いても同様に有用な ッールとなりうることが期待される.ゴルジ装置ダイナミク スに作用する薬剤は非常に限られている状況であることか ら，作用物質の探索を行うことにした．糖タンパク質の細胞 内輸送阻害剂を探索してその作用を解析し，その多くが細胞 内輸送をゴルジ装置で止めることを明らかにしてきた。この 結果はこれらの薬剤がゴルジ装置に作用している可能性を 示すことから，ブレフェルジン $\mathrm{A}$ やノダゾールで処理す るとゴルジ構造体は消失するが，これらの作用は可逆的で除 去するとゴルジ構造体が速やかに再構築されることを利用 して，ゴルジ装置ダイナミクスへの作用を検討した．

メパニピリムは防徽剂として市販されており糸状菌の酵 素の分泌を阻害することが明らかにされていたが，動物細 胞においてもウイルス糖タンパク質の細胞表層出現を抑制 する，本論文では薬剤で誘起されたゴルジ装置の分散をメ パニピリムが阻害することを見いだし，その作用について 解析した結果について報告した。その概要を解説するとと
あに，中心体に作用することなどのその後の知見を踏まえ て，中心体がゴルジ装置の構築と構造維持に関与する可能 性についてむ言及する。

$$
\begin{gathered}
\text { メパニピリムによるゴルジ膜タンパク質の } \\
\text { 逆行移行の阻害 }
\end{gathered}
$$

培養動物細胞をブレフェルジン A で処理するとゴルジ 装置は消失し, ManII や Helix pomatia レクチンと反応す る糖タンパク質などのゴルジ膜タンパク質は小胞体に逆行 移行する (Fig. 1: b ，f). メパニピリム処理でゴルジ装置の 構造は異常にはなるが (Fig. 1: c, g)，逆行移行は抑制され て核周辺に留まったままである (Fig. 1: d, h). ブレフェル ジンAによる逆行移行誘起に先だって逆行移行を司る輸 送小胞のコートタンパク質である $\beta$-COP が遊離すること が必要条件であるとも考えられているが，この過程には作 用しない. また，ブレフェルジン A 除去後のゴルジ構造体 の再構築 (Fig. 5) や新たに合成されたウイルス糖タンパク 質の小胞体からゴルジ装置への順行移行には作用しない. ブレフェルジン $\mathrm{A}$ とは作用の異なるノルジヒドログアイ
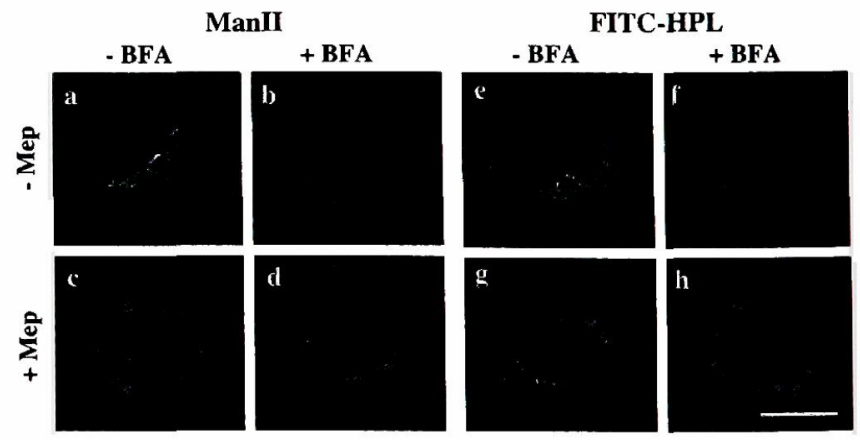

Fig. 1. Mepanipyrim Inhibited BFA-Induced Retrograde Golgi-to-ER Trafficking in NRK Cells. NRK cells incubated in the absence (a, b, e, and f) or presence (c, d, g, and $h$ ) of mepanipyrim were false-treated ( $a, c, e$, and $g$ ) or treated $(b, d, f$, and h) with BFA. Fixed cells were processed for (immuno)cytochemical staining for ManII (a-d) and with FITC-HPL (e-h). Bar, $10 \mu \mathrm{m}$. 

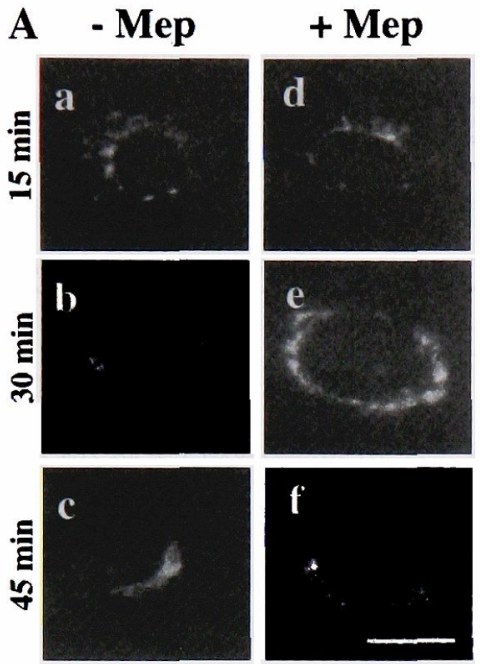

Fig. 5. Mepanipyrim did not Inhibit Anterograde Trafficking of Golgi Proteins.

NRK cells treated with BFA were incubated in the presence of BFA $(a-c)$ or BFA and mepanipyrim (d-f). Anterograde trafficking of ManII in the absence $(a-c)$ or presence of mepanipyrim $(\mathrm{d}-\mathrm{f})$ after BFA removal was followed at indicated times. Bar, $10 \mu \mathrm{m}$.

アル酸，アラキドン酸トリフルオロメチルケトンによるゴ ルジ膜タンパク質の逆行移行む阻害することは, メパニピ リムはゴルジ膜タンパク質を核近傍に強く係留する作用を 有しており，その結果として薬剤で誘起された逆行移行を 阻害することが考えられた。

\section{メパニピリムは微小管を破壊しても \\ ゴルジ装置の分散を抑制}

ゴルジ装置の核近傍への係留は微小管に依存すると考え られている. 事実, ノコダゾールなどで微小管を破壊する と断片化して細胞質に散らばる。 また, 細胞分裂期のゴル ジ構造体の消失は, 細胞分裂期に細胞質微小管が消失し, 代わって，紡錘糸が形成されることに起因していると考え られている。しかし，メパニピリムはノコダゾールによる 微小管破壊には作用しないにもかかわらず(Fig. 7A), 断片 化されたゴルジ装置の分散を抑制する(Fig. 7B). ノコダゾ ールに限らず，コルヒチン，ビンブラスチンなどの作用の 異なる薬剤で微小管を破壊してあ同様の結果が得られた。 微小管を破壊してあゴルジ装置が核近傍に係留されること から, 微小管はゴルジ装置の槽状構造の維持には機能して いるが核近傍への係留には一義的には機能していないと考 えられる。

\section{ゴルジ装置と中心体}

ゴルジ装置の核近傍への係留に微小管がかかわっていな
A
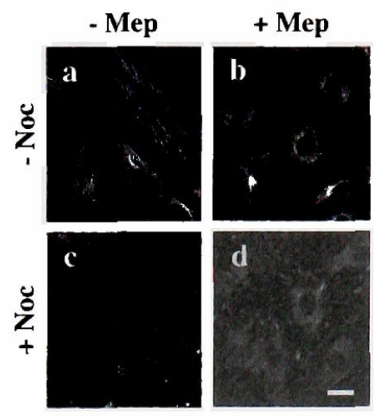

$\mathbf{B}$

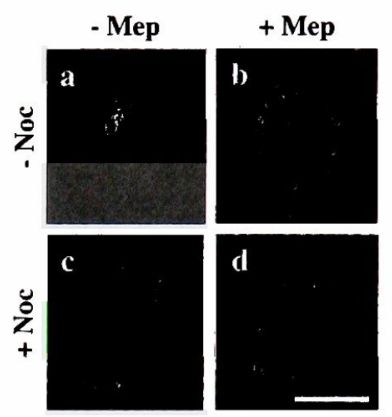

Fig. 7. Mepanipyrim Blocked Nocodazole-induced Fragmentation and Dispersion of the Golgi without Preventing Microtubule Depolymerization.

NRK cells incubated in the absence ( $a$ and $c$ ) or presence of mepanipyrim (b and d) were false-treated ( $a$ and $b$ ) or treated with nocodazole (c and d). Fixed cells were stained for $\alpha$-tubulin (A) and ManII (B). Bar, $10 \mu \mathrm{m}$.

いとすれば，それに代わるものは何かという問題が残る. 細胞分裂期にゴルジ装置が消失することはすでに述べた が, 細胞周期の全期で一部のゴルジ膜タンパク質は中心体 と強く結びついていることを見いだした。このことは中心 体がゴルジ装置の核近傍への係留に機能している可能性を 示唆する．核近傍に位置している中心体でゴルジ装置が係 留されているこよは，両者の空間的な配置のみならず，コ ルジ装置ダイナミクスが細胞周期経過と同調していること にとってあ好都合であると考えられる。事赛, 細胞周期を 制御するプロテイン・キナーゼのいくつかが中心体とゴル ジ装置の両方に存在する。ゴルジ装置が核近傍には係留さ れてはいるものの中心体とは離れた位置に存在する場合む 多いことは，中心体との直接的な関係を示すことには無理 があったが，両者を結びつける構造体を見つけることがで きた．これらの結果は，ゴルジ装置の構造維持とダイナミ クスに中心体が関与していることへの期待を抱かせるもの であると考える。

\section{おわりに}

メパニピリムが薬剂で誘起されたゴルジ装置の分散を抑 制することとと屯に，微小管を破壊してもゴルジ装置は核 近傍に係留されることを見いだした，本論文では中心体の 機能を考察したが，その後，メパニピリムが中心体の機能 に作用していることを示す結果を得た．ゴルジ装置ダイナ ミクスの研究にメパニピリムが有用なッールとなることを 期待している.

末筆になりましたが，本論文賞に選考していただきまし た委員の諸先生に厚く御礼申し上げます. 